\title{
ПРИРОДНЕ ТА ШТУЧНЕ В ЛЮДСЬКІЙ БУТТЕВОСТІ
}

\section{Л.Л. Матвєєва}

Поняття природного та штучного є одними 3 найбільш активно вживаних у контексті філософських досліджень,- - насамперед культурологічної, антропологічної, естетичної спрямованості. Причому у переважній більшості випадків їх зіставлення поки що розуміється як опозиційна смислова конструкція. Навіть саму культуру як специфічну форму людської життєдіяльності дослідники нерідко намагалися й намагаються не просто протиставити природі як дещо штучне, а й навіть сутнісно визначити через це протиставлення. Поява та розвиток у наш час деяких невідомих раніше технологій і явищ, таких як біотехнології, занепокоєння зростанням питомої ваги техніки у людському житті або екологічними негараздами тільки посилюють актуальність осмислення взаємодії категорій штучного й природного, викликаючи нові й нові хвилі обговорень.

Звісно, не варто заперечувати певну результативність протиставлення штучного й природного саме як людського й позалюдського (або ще й культурного та позакультурного) буття. На боці такого підходу достатньо давня світоглядна традиція. На протязі тривалого періоду культурного розвитку протиставлення штучного природному сприяло набуттю людством усвідомлення своєї унікальності. В. Татаркевич, наприклад, пише: «Розрізнялися й розрізняються (як у філософії, так і в повсякденному мисленні) два види буття: те, що є частиною природи, i те, що створила людина. Таке розрізнення ще в давнину запровадили греки, розмежувавши те, що походить ,із природи“ (fysei), і те, що походить із мистецтва або з людських витворів (nomo, thesei)» [12, c.8]. Підтримується таке розрізнення природного і штучного і бага-

Актуальні проблеми духовності: зб. наук. праць / Ред.: Я.В. Шрамко Вип. 10. - Кривий Ріг, 2009, 14-29 
тьма сучасними українськими науковцями. «Терміни „природний об'єкт“ і „штучний об'єкт“ визначають з урахуванням, хто є їхнім творцем, автором, креатором; хто „породив“, створив їх. Природа чи сама людина? Відповідно, об'єкти, „створені“, „породжені“ Природою, є природними, а об'єкти, які створила людина, є штучними» [4, с. 28]. Існують, звісно, й концепції, які намагаються пояснити логіку й необхідність формування штучного простору у людській культурі. Так, С.А. Дзикевич бачить у створенні людиною штучних об'єктів реалізацію потреби фізичного утвердження себе у бутті. Зокрема, у зв'язку з проблемами творення штучного речового простору і свого роду «турботою» людини про штучне середовище, він пише: «Будучи зачепленням і через нього - обгрунтуванням в світі інших актуально існуючих предметів, таких, що протистоять, опозиційних і разом з тим, мабуть, ворожих, відторгаючих, ця турбота повинна виявлятися в тому, щоб з'єднати себе в тому або іншому ступені насильницьки з цим світом через підпорядкування автономії „я“ деяких предметів світу. Це підпорядкування повинно бути здійснено фізично, бо мета його полягає саме в тому, щоб закріпитися в існуванні як фізичній присутності через зчеплення з цим світом того, що фізично існує, тому буття через пізнаване буття у цьому вигляді виражається у фізичній формі» $[1$, c. 70-71].

Однак насправді не все з використанням понять природного й штучного є таким очевидним. По-перше, сьогодні нас оточує безліч так би мовити амбівалентних відносно поняття природності-штучності речей. Взяти хоча б ситуації, коли ми говоримо про натуральні (лат. natura природа) чи штучні тканини, про натуральні або штучні імплантанти, займаємось штучним підтриманням стану природного середовища і біоценозу у природоохоронному заповіднику тощо. Крім того, окремою проблемою є те, що поняття штучного не тільки у ментальності пересічної людини та у нашому повсякденному мовленні часто отримує скоріше негативне, ніж позитивне смислове наповнення, але така позиція характерна й для багатьох наукових концепцій. Відомо, наскільки критично у наш час оцінюється вплив людської цивілізації на оточуюче середовище. Нерідко така критична позиція апріорі виходить з того, що техніка протистоїть природі по суті. А будь-яке втручання людини у природне середовище, що веде до його змін, оцінюється негативно - йдеться про формування нового ландшафту або про зникнення внаслідок людської активності якого-небудь виду рослин чи тварин. Негативно в значній кількості випадків оцінюються і зміни, що відбуваються в якостях і властивостях самої культури. Досить не 
випадковим виглядає у такому контексті й зауваження Г.Плеснера, який поза своїм визнанням у роботі «Ступені органічного й людина. Вступ до філософської антропології» того, що «штучність людини являється сутнісним вираженням її природи» [9, с.273], так званий закон «природної штучності» все ж коментує наступними словами: «Цей основний закон власного існування усвідомлюється людиною у надзвичайно різноманітних формах і відтінках значень, але до нього завжди домішується гіркота від усвідомлення недосяжності тієї природності, яка властива іншим живим істотам» [9, с.268]. Значно радикальніша позиція висловлюється у наукових публікаціях В.А.Кутирєва, у яких йдеться, зокрема, й про небезпеку створення внаслідок розвитку сучасних технологій «постлюдяної» реальності ${ }^{1}$. Значно менш поширеним $\epsilon$ аналіз тих ризиків, які несе за собою консервативне, ортодоксальне ставлення до культурних змін та технічного прогресу. Серед порівняно небагатьох таких робіт привертає увагу дослідження Фрітца Рінгера «Сутінки німецьких мандаринів. Німецьке академічне співтовариство, 1890-1933», у якому йдеться про ту роль, яку зіграли у світоглядній кризі та, зрештою, історичній провині Німеччини ХХ століття, поширені серед освічених представників німецького суспільства уявлення про «кризу культури», «кризу духу», «кризу цінностей»у «бездушну» технологічну епоху [10].

За таких обставин з'являється потреба й необхідність не тільки усвідомлення людиною своєї приналежності до природи поза всією специфікою людськості, а й більш детального аналізу самої сутності штучного, яке також є невід'ємною складовою Dasein (М. Хайдеггер) людини, актуалізується перегляд розуміння поняття штучного як дечого цілковито опозиційного до природного. Відповідно, у даній публікації ставиться за мету аргументувати таку інтерпретацію понять природного й штучного, яка буде виходити не з жорсткого й статичного опозиційного їх протиставлення, а з розуміння штучного як свого роду природного новоутворення та поступового оновлення його предметного змісту, - що й закладає динамічну нестабільність змістовності обох понять. Викладена у даній статті інтерпретація штучного як природного новоутворення дозволяє осмислити людську діяльність як дещо

\footnotetext{
${ }^{1}$ Див. зокрема: Кутырев В.A. Естественное и искусственное: борьба миров.Н. Новгород: Издательство «Нижний Новгород», 1994; Кутырев В.А. Прельщение бессмертием (об абиотических тенденциях современной цивилизации) // http://aquarun.ru/aquarius/futurenet/immort.html; Kутырев В.А. Философия Иного, или небытийный смысл трансмодернизма // Вопросы философии. - 2005. № 12 . - С. 3-19
} 
сутнісно закономірне і буттєво обумовлене, що, у свою чергу, передбачає більш позитивне й конструктивне сприйняття не тільки наслідків взаємодії людини з природою, але й тих внутрішніх трансформацій, що відбуваються з часом в самій культурі.

Джерелом будь-якого штучного предмету або явища у культурі $€$ людська творчість, яка визначається як діяльність, що породжує дещо якісно нове, таке, якого ніколи раніше не було. Причому поняття творчості (на відміну від «творіння») у більшості випадків співвідноситься з виключно людською формою життєдіяльності, - відповідно до інтерпретації діяльності як специфічно людського ж активного відношення до оточуючого світу. Однак підхід до феномену людської творчості у онтологічному ракурсі дозволяє співвіднести цю творчість не тільки з поняттям діяльності, але й активності (лат. actus - дія; actualis дієвий; actum - діяння, подія; activus - активний, діяльний). Крім того, враховуючи, що середньовічне латинське actualis окрім «діяльний» означало також «сучасний», «наявний», а останні $є$ поняттями, близькими за смисловим значенням до таких як «теперішній» i «реальний», то очевидним стає семантичний зв'язок смислових змістів активності, діяльності - і реальності, теперішнього. I хоча сама активність, діяльність можлива (для осмислення і не тільки) лише за умови допущення певного існування, однак, з іншої сторони, саме активність (діяльність) обумовлює можливість певної реальності або як теперішнього (у менш широкому значенні), або ж як сущого, буття (у більш широкому значенні). Цей взаємозв'язок і взаємозалежність здавна виступали предметом уваги філософів, - згадати хоча б аристотелівське вчення про «дійсне» і «можливе» у відповідь на одну з апорій елейської школи, або більш пізнє actus et potentia у схоластиці. Тому немає потреби зупинятись на цьому детальніше і можна перейти до наступного: а саме звернути увагу на те, що у різноманітних природничонаукових контекстах також доволі широко використовується поняття активності, близьке, як вже говорилось, у семантичному плані до понять діяльності й творчості. Наприклад, може вестись мова про хімічну, геологічну, біологічну активність. Відзначимо, що у всіх подібних випадках дослідження тієї чи іншої форми активності сущого, її умов і результатів вважається пізнанням властивостей і процесів й не має на меті формування аксіологічної характеристики. Вивчаючи хімічні реакції, геологічні процеси або біологічну еволюцію ми говоримо частіше і більше про те, що виникає нового у результаті цієї активності, ніж про те, які попередні форми й стани втрачаються. Але коли справа доходить до аналізу наслідків активності чи результатів діяльності самої людини, 
то тут починають домінувати зовсім інші підходи й оцінки.

Причиною поширених песимістичних оцінок перспектив взаємодії людської цивілізації з першою, «докультурною» природою та теперішнього і майбутнього культури є комплекс декількох суб'єктивних й об'єктивних чинників. У одній з моїх публікацій вже йшлося про деякі причини свого роду культурно-етичного песимізму та про роль художньої культури у його підтриманні [8]. У зв'язку ж з проблемою природного й штучного варто звернути увагу на ще один психологічний аспект, а саме на відому суперечність, що існує між інтенцією людини до руйнування існуючої в тому або іншому плані стабільності й рівноваги з метою досягнення нових результатів, можливостей, інформації i навіть просто переживань, - i протилежною їй інтенцією до збереження стабільності, рівноваги й сталості навколишнього середовища. Мабуть, саме одночасна наявність в людській психіці цих різноспрямованих інтенцій не в останню чергу відповідальна за парадоксальне поєднання нестримного прагнення до, наприклад, технологічного прогресу на діяльному рівні, - і надзвичайно низької (деколи навіть негативної) оцінки результатів і спрямованості цього процесу.

Варто звернути увагу навіть на таку незначну на перший погляд деталь, як послідовність згадки в різних наукових контекстах вищезазначених протилежних устремлінь людини відносно стабільності. Як правило, першою згадується або описується інтенція до встановлення і підтримки постійності, а вже потім висловлюється протилежне прагнення до новизни. Таким чином виникає певна розстановка смислових акцентів: нібито потреба в незмінності і стабільності доповнюється (або «розхитується») потребою в змінах. Чи ж інакше: традиція доповнюється новаторством. У такому разі домінуючим, основним поняттям (мислеформою) виступає саме стабільність, незмінність, традиція. Насправді ж в онтологічному ракурсі більш адекватним є інший варіант конструкції, - тобто спочатку новизна, новаторство, а вже потім стабільність і традиція. Бо «новизна», «зміна»- це, по суті, суб'єктивна інтерпретація людиною-«спостерігачем» якогось моменту того загального руху, який, як відомо, є способом існування матерії, тоді як стабільність забезпечує переважно власну сталість й ідентичність людини. (Ситуація до певної міри нагадує суперечки між геліоцентричною й геоцентричною системами інтерпретації сонячної системи, які точились більше двох з половиною тисяч років.) 3 іншої сторони, принагідно тут буде згадати й інтерпретацію традиції М. Хайдеггером, який звертав увагу, що традиція - це не минуле, а фактично те, що ми створюємо, мислимо зараз: «Традиція - це сучасне, яке виходить 
3 того, що ми відшукуємо традиційне мислення в тому місці, в якому воно бере початок, переносячи нас через самих себе настільки далеко, наскільки це можливо, і таким чином спеціально включаючи нас в традицію» $[13$, с.86]. 3 усього виходить, що інколи сучасність і новизна можуть, в принципі, здійснюватись у мінімізованому зв'язку з традицією, але взагалі в жодному разі не існує традиції поза сучасністю (тобто як традиція осмислюється лише те, що сприймається, мислиться зараз). Можна сказати й так, що традиція $є$ віртуальним фрагментом теперішнього, яке постійно рухається у майбутнє.

Специфічною формою буття людини є культура. Варто звернути увагу, що навіть етимологія слова «культура» знову повертає нас до проблеми нашої взаємодії з природою. Бо латинський прототип цього сучасного слова означав не що інше, як певні дії і наміри людини щодо природи. Ці дії і наміри можуть бути виражені у семантичному «перетині» понять обробки, розвитку, виховання і т. п. Таким чином, вже в самій лексемі «культура» міститься певне креативне звернення людини до простору, з якого вона, людина, походить. Причому, з одного боку, у первинному понятті культури природа розглядається як деякий сакральний простір, в якому діяльність людини набуває рис сакрального ж ритуалу (свого роду богослужіння). 3 другого ж боку, цей ритуал не тільки припускає, а й навіть спрямований саме на зміну первинно наявного сакрального простору природи. Образно кажучи, ритуал, що проводиться в храмі, полягає в безперервному будівництві цього храму. Не можна, на мій погляд, не помітити, що метафоричний образ природи як храму, що вічно будується, досить узгоджується 3 філософською тезою про рух як спосіб існування матерії. Популярне в Новий час розуміння людини як «вінця творіння», поза всім сучасним скептицизмом щодо цієї думки, має таки певне підгрунтя. Можна погодитись, що досягнення форми самоусвідомлюючого суб'єкта було метою і результатом всієї біологічної еволюції. Проте людина за своєю суттю не може бути визначена як істота біологічна. Застосування до людини формулювання «представник однієї з родин людиноподібних мавп ряду приматів класу ссавців», як то іноді (хоча і з застереженнями) робиться, є абсолютно некоректним. Це майже те саме, що визначати рослину або тварину через склад (у відсоткових пропорціях маси або ваги) хімічних елементів, що складають їх тіла. Формально все буде нібито вірно. Дійсно, будь-який живий організм складається виключно із хімічних елементів всім відомої таблиці Д. Менделєєва, і кількість кожного з них у будь-якому живому організмі можна, в принципі, виміряти. Але ж в рослині чи тварині хімічні елементи i 
сполуки не визначають їх суть. Головним, визначальним тут $є$ те, що вони представляють відмінну від неорганічної- органічну форму існування матерії, є живими організмами (хоча і складаються з тих самих хімічних елементів, що і неживий світ). Подібно і з людиною, -хоча серед іншого вона є біологічною істотою, проте сутність людини не визначається через їі біологізм. Тут можна пригадати й релігійне положення, згідно з яким людина є суттю, подібною Богу (бо створена ним «за образом своїм і подобою»). Якщо ж основною суттю Бога $€$ саме його іпостась Творця, то креативні інтенції людини цілком 3 цією божественною суттю узгоджуються. Як би там не було, важко заперечити логіку, згідно з якою притаманні неживій, а потім і живій природі форми активності, що ведуть за собою трансформації й змінення самої природи, повинні мати певні відповідники (хоча, звісно, й не йдеться про прямі паралелізми) на рівні культурного існування. Варто знову згадати М. Хайдеггера, який писав: «Ми можемо говорити про те, що царства природи й історії не так сильно й жорстко відділені один від одного, як це могло б здатися при погляді на розрізненість факультетів університету» [13, с. 55].

Переходячи до іншого аспекту співставлення природного й штучного насамперед зазначу, що ефективним свого роду «лакмусовим папірцем» щодо дотримання логічності при аналізі проблем опозиційності природного й штучного видається питання каузальності. Н. Карамишева, посилаючись на Г. Саймона [11], пише: «Штучні об'єкти людина конструює, створює на основі принципів вузької функціональності, доцільності, пристосування до вимог природного середовища та раціоналізації життєдіяльності суспільства, а описують їх шляхом вказування організації та принципів використання (роботи) під час процесу взаємодії з людиною», наголошуючи при цьому на принципах «точно визначеної функціональної організації та оптимальності цільового використання штучних об'єктів» [4, с. 30]. Можна погодитись, що створюються штучні об'єкти людиною дійсно на основі насамперед апеляції до конкретної (а часто й вузької) функціональності й доцільності. Однак дійсна функціональність й реальне використання штучних об'єктів значно відрізняються своєю широтою й непередбачуваністю від запланованих і врахованих при їх створенні. Все життя людини і весь культурний простір наповнені цією непередбачуваною функціональністю об'єктів культури. Це відбувається тоді, коли втомлена людина спирається як на посох на лопату, якою вона щойно працювала, і тоді, коли згадує граблі як натяк на нездатність окремих людей навчатись на власних помилках; коли згорнутою газетою намагається поціли- 
ти надокучливу муху і коли відомим газованим напоєм знімає накип з чайника; тоді, коли людина колекціонує сірникові коробки, і коли вона, наприклад, віником карає шкідливе цуценя. Але ж для чого задумувались й створювались всі ці згадані предмети? Та сама довільність і непередбачуваність відбувається і з використанням символів, понять, цінностей і загалом смислів культури. Тож слід визнати, що реальне функціонування штучних об'єктів далеко не обмежується безпосередньою причиною їх створення, а залежить у кожному окремому випадку від волі, потреби й уяви людини, що обумовлені її свідомістю.

Цікаво й певною мірою показово, що логіка міркувань щодо доцільності й функціональності об'єктів нерідко порушується вже на матеріалі аналізу більш «раннього» еволюційного фрагменту буття, ніж той, який прийнято інтерпретувати як штучний, - зокрема, при порівнянні об'єктів живої й неживої природи. Як до подібного, на мій погляд, непереконливого, сумнівного прикладу приписування фрагментам (органам) живих організмів занадто жорсткої каузальності можна звернутися до зіставлення І. Кантом таких об'єктів як людське око і камінь. $\mathrm{y}$ «Першому вступі до критики здатності судження» Кант пише, що структура ока «містить умови цього його можливого застосування i, отже, містить каузальність згідно механічним законам. Але я можу також використати камінь, щоб розбити щось або що-небудь побудувати на ньому і т. д., і ці дії також можуть бути співвіднесені з своїми причинами як цілі, проте на підставі цього я не можу сказати, що камінь повинен був служити для будівництва. Лише про око я висловлюю думку, що воно повинно було годитися для зору, і хоча зовнішній вигляд, властивості всіх частин ока і їх поєднання, що розглядаються за суто механічними законами природи, абсолютно випадкові для моєї здатності судження, все ж таки у формі і в будові ока я мислю необхідність бути сформованим певним чином, а саме згідно поняттю, яке передує причинам, що формують цей орган; без цього поняття можливість даного продукту природи я не осягну ні за яким механічним законом природи (чого не буде з каменем в приведеному прикладі). Ця обов'язковість містить необхідність, явно відмінну від фізико-механічної необхідності, відповідно до якої річ можлива згідно одним лише законам діючих причин (без попередньої ідеї речі), і їі також не може бути визначено чисто фізичними (емпіричними) законами, як необхідність естетичної думки психологічними законами; ця обов'язковість вимагає власного апріорного принципу в здатності судження, оскільки вона рефлектуюча; цьому принципу підкоряється телеологічна думка, і з нього ця обов'язковість і повинна бути визначена відповідно до іiї 
значущості і обмеження» [3, с. 146-147].

Проте, на мій погляд, якщо відступитись від невідворотної суб'єктивності при порівнянні власного органу й стороннього предмету, то з онтологічної точки зору не тільки око, але і камінь мають досить подібну (повторю далі слова Канта) «необхідність бути сформованим певним чином, а саме згідно поняттю, яке передуе причинам, що формують» їx. Такою об'єднуючою існування ока і каменя каузальністю виступає перш за все (або як мінімум), визначена єдністю буття необхідність зв'язку і взаємодії. У разі ока можна сказати, що воно $\epsilon$ окремим наслідком (або результатом) необхідності відчуття, сприйняття, тобто інформаційного зв'язку між живим суб'єктом і оточуючим його світом. I, до речі, цю потребу або необхідність може задовольняти не тільки око, але крім того тактильні, смакові, слухові й інші органи і рецептори. Тобто необхідність даного виду зв'язку може задовольнятися різними способами (пригадати синергетику з її ідеєю обмеженої варіативності); навіть та ж фізіологія зорових рецепторів буває вельми різною. Крім того, деякі з живих істот очей не мають взагалі, обходячись іншими формами зв'язку з оточуючим середовищем. Таким чином, око є тільки частковим прикладом більш загального каузального зв'язку.

Так само камінь є частковим прикладом реалізації зв'язку і взаємодії елементарних частинок неживої матерії. А конкретний приклад цього зв'язку вже з необхідністю зумовлює властивості саме цього каменя і його форму. Причому так само, як в процесі інформаційного зв'язку живої істоти зі світом відбувається взаємодія (і окреме питання: одностороння або обопільна - за Кантом, до речі, як і з позиції сучасної фізики, відбувається саме обопільна взаємодія суб'єкта (спостерігача) і об'єкта), так має місце і взаємодія у формах і між формами неживої матерії. А чи розбиваємо ми щось за допомогою каменя, або використовуючи камінь будуємо що-небудь - це вже окремі приклади реалізації людиною можливостей взаємодії матеріальних форм. I можливості ці, до речі, залежать не тільки від «фізико-механічних» (словами Канта) властивостей каменя; так само, як можливість бачити залежить не тільки від фізико-механічних же властивостей і будови ока. Важливо звернути увагу на те, що, строго кажучи (і відійшовши від звичних штампів повсякденної мови), бачимо ми не оком, а за допомогою ока, причому подібно тому, як розбиваємо або будуємо теж не каменем, але за допомогою каменя! Діючою ж активною силою в обох випадках виступає перш за все людська свідомість і воля.

Для більшої ясності суті заперечень щодо приклада I. Канта їх мо- 
жна викласти і в дещо іншому ракурсі. А саме зазначити, що конкретне «застосування» людиною (і не тільки людиною) ока так само не передбачене в його «фізико-механічних» властивостях, як і застосування каменя. I камінь, і око володіють якимись фізичними властивостями. Камінь має форму, масу, щільність, хімічний склад, здатність відображати від своєї поверхні оптичне випромінювання і ін., і ін. Око, крім всього цього, - ще і здатність певним чином перетворювати світлове випромінювання в сигнали для мозку. Але як властивостями каменя не зумовлено, чи повинно його освітлювати сонце або зрошувати дощ, будувати з нього дім або бити ним по іншому каменю, так і властивостями ока жодною мірою не зумовлено, чи буде воно спрямовано на дерево або зоряне небо. Крім того, не дивлячись на конкретику фізичних умов віддзеркалення оптичного випромінювання і сприйняття цього віддзеркалення зоровим органом живої істоти, не зумовлений цими фізичними умовами і результат такої взаємодії (хоч і обмежений у варіантах). Повторюся, що людина бачить не оком, а за допомогою ока, тобто насправді людина бачить не відображене оптичне випромінювання саме по собі, а певні «предмети», тобто створені культурою знаки і сенси. I взаємозв'язок сприйнятого оком оптичного випромінювання 3 тим, що людина за його допомогою «бачить» своєю свідомістю не менш варіативний, ніж можливості застосування каменя. Строго кажучи, око в такій же мірі не створене для якогось «бачення» саме конкретних предметів (вірніше, сенсів, знаків), як і камінь не створений для якогось конкретного його функціонування. Уявімо, що може «бачити» «людина» повністю позбавлена людської свідомості? Або ще кращий приклад - уявити технічний прилад, який, сприймаючи оптичне випромінювання, повністю технічно копіює механізм функціонування людського ока... Тож виходить, що людина користується і власним оком, і каменем, надаючи їм при цьому однакову каузальність - каузальність згідно використання у постійно триваючому творчому функціонуванні смислового простору культури. У цьому смисловому просторі і око, і камінь забезпечують ряд можливостей: камінь - фізичних маніпуляцій-взаємодій, око ж-смислових. Таким чином, повторюсь, можна говорити про те, що як око, так і камінь не створені для якого-небудь конкретного їх застосування, але допускають можливість того або іншого їх застосування. Що ж стосується ймовірного заперечення, що, мовляв, око у людини повинне бути, а камінь - не обов'язково, то, по-перше, не зовсім коректно порівнювати власний тілесний орган і зовнішній предмет. А по-друге, замість ока у живої істоти, в принципі, можуть бути й інші засоби зв'язку з 
оточуючим світом, а замість каменя у розпорядженні людини можуть бути якісь інші достатньо тверді фізичні об'єкти. Не треба, мабуть, доводити безглуздість ідеї еволюційного формування людини в нематеріальному просторі або вакуумі.

Подібним чином будь-яка створена людиною, тобто «штучна» річ, з одного боку, не може не відповідати всім законам природи, але з іншого - використовується (тобто функціонує у культурному просторі) тільки за умови обов'язкового осмислення її самої та ситуацій її використання, або, принаймні, прийняття вольового рішення (що, знову ж таки, передбачає осмислення бажання). Найсучасніша технологічна розробка не $є$ такою, наприклад, для людини з примітивного племені амазонських джунглів. Більш того, каузальність каменя буде для неї набагато очевиднішою, як і загалом його, каменя (знову повторю слова I. Канта), «необхідність бути сформованим певним чином, а саме згідно поняттю, яке передує».

Зрештою, І. Кант і сам неодноразово звертав увагу на відносність визначення наявності доцільності речей. Й іноді, до речі, при тому прямо асоціюючи проблему доцільності з поняттями природності й штучності (змайстрованості). У одному з таких фрагментів, у контексті аналізу телеологічної проблеми, Кант, навівши приклади «придатності деяких природних речей як засобів для інших творінь», пише: «Отже, об'єктивна доцільність, яка грунтується на придатності, не є об'єктивна доцільність речей самих по собі, неначе пісок сам по собі не можна зрозуміти як дію своєї причини-моря, не надаючи останньому цілі і не розглядаючи дію, а саме пісок, як витвір мистецтва. Це тільки відносна, чисто випадкова доцільність для самої речі, якій вона приписується; і хоча в наведених прикладах трави самі по собі слід вважати продуктами органічної природи, отже чимось змайстрованим, але по відношенню до тварин, які ними харчуються, їх треба розглядати як грубу матерію» [3, с. 392-393]. Таким чином, в даному випадку Кант визнає, що доцільність $\epsilon$ відносною, а отже предмет може бути інтерпретований як штучний або природний залежно від точки зору, або свого роду системи координат.

Урахування відносності інтерпретації об'єктів як природних або штучних веде до визнання суб'єктивної урівненості об'єктів у аспекті їх використання людиною. Для з'ясування ж об'єктивної сторони варто тільки поставити питання: чи $\epsilon$ аргументи, які б свідчили на користь зупинення з якоїсь причини тих еволюційних змін, яких Всесвіт зазнав за останні приблизно 15 мільярдів років, а наша планета - за приблизно $4,5-5$ мільярдів? Особисто я таких аргументів зупинення 
руху, змін, еволюції не знаходжу. Як не знаходжу і причин, з яких би людина була усунена від участі у цьому процесі. Те саме стосується й проблеми збереження ідентичності самої людини, про що так багато говорять критики розвитку сучасних біотехнологій. Детальніше ця проблема висвітлювалась мною у окремій публікації [6], зараз же можна обмежитись запитанням: а чому, власне, «зберігати» треба ідентичність саме людини сучасного типу, - чому б тоді не піднімати питання «жахливих наслідків» втрати ідентичності людиною кам'яного віку (чи й навіть біологічних й психосоматичних особливостей ще більш раннього нашого предка), або хоча б втрати ментальної ідентичності наших предків тих часів, що передують формуванню сучасної національної ідентифікації?

Нарешті, якщо піднімати питання про першооснови буття, то найбільш глибокою видається його обумовленість самою дилемою буттянебуття. Іншими словами, першооснова - це можливість бути і (або) не бути. 3 цієї першооснови виходить і все подальше поєднання різноспрямованих інтенцій, можливостей, тенденцій і т. д. аж до людських понять добра і зла. Природа ніби одночасно $є$ i не $\epsilon$, 一 щось $є$, щось тільки можливе. В людині так само співіснує і дійсність, і ще тільки можливість. Людина своєю активністю, діяльністю, творчістю поступово переводить можливе природи в їі дійсне. При цьому ми називаємо штучним те, що саме людиною актуалізується в природі.

На перший погляд, друге начало термодинаміки свідчить про наявність меж можливості створення штучного як новоутворення природного. Однак чи дійсно такі межі не уникненні? Вяч. Іванов щодо поняття ентропії наводить наступну метафору: «Перше, те, що повинне бути всім відомо з середньої школи, це той напрям часу, який пов'язаний з другим законом термодинаміки, а саме зростання ентропї, тобто, дуже грубо кажучи, збільшення ступеня неорганізованості світу. Я завжди з приводу цієї ідеї повторюю приклад, який якось чув від одного свого приятеля, котрий відрізнявся такою ж неакуратністю, як і я, відносно книг, потрібних для писання якого-небудь твору. Він говорив, що книги, розставлені на полиці, знаходяться у повному порядку (точніше, бажано, щоб вони були у повному порядку). Ти починаєш писати, і книги поступово накопичуються на столі - одна стопка книг, інша, потім вони починають звалюватися на підлогу. Юрій Михайлович Лотман вражав мене тим, що в його величезному кабінеті в Тарту були такі спеціальні містки, з дощечок, по яким він пересувався від однієї стопки книг до іншої. Ось це і є зростання ентропії. На початку ми маємо добре організовану систему книг на полиці, потім збільшу- 
ється безлад, збільшується у міру того, як ми пишемо, тобто у міру того, як час рухається у бік майбутнього» [2]. Проте у змальованій В. Івановим картині, слід, на мою думку, звернути увагу на наступне. Неорганізованість зростає не просто за мірою того, як рухається час, а за мірою того, як ми виконуємо якусь роботу (у прикладі В. Іванова неорганізованість книг зростає за мірою того як ми пишемо, тобто створюємо ще одну, нову книгу). Інакше кажучи, у процесі зростання хаосу народжується новий порядок. Беручи приклад з В. Іванова дозволю й собі навести метафоричне порівняння. Коли живописець тільки планує приступити до роботи, фарби, якими він буде працювати, знаходяться кожна у своєму тюбику, у порядку. Коли ж живописець починає працювати, він вичавлює фарби на палітру, змішує їх між собою, накладає на полотно (часто у доволі хаотичний спосіб), видаляє залишки тощо. Колишній порядок між фарбами зникає. Але при цьому як принципово інший (і вищий у порівнянні з простотою послідовного розташування фарб кожної у своєму тюбику) з'являється порядок живописного твору, порядок художнього образу.

Подібно й кожне штучне руйнує порядок існуючого природного, змінюючи, перетворюючи, а інколи по суті й знищуючи його. I чим більшою є творча свобода, тим більшою $є$ випадковість, непередбачуваність майбутнього. А звідси і його неорганізованість відповідно до саме тут і зараз існуючих принципів, структур, форм і порядку. Твір ще не створений є можливістю будь-чого, а тому звідси (з теперішнього часу) - абсолютним хаосом і принциповою відсутністю форми. Саме тому, шукаючи опори для власного буття, виправдання власного існування як дечого наявного, оформленого, здійсненого, людина воліє апелювати більше до дійсності природи (традиції, природності) й ігнорувати їі можливість (новоутворення, штучне). Але можливість «стукає у двері», тривожить людину, потрохи відкриваючись їй у відчуттях, які означаються у поняттях інсайту, духовного, естетичного. Відтак можливість природи людиною відчувається як власне натхнення, власна уява, яка реалізується у різних формах культурної творчості, - технічної, наукової, художньої.

Звісно, поняття ентропії вимагає від метафор (які все ж таки завжди пов'язують об'єкти тільки за їх окремими, частковими якостями й рисами) знову повернутись до більш цілісної й грунтовної інтерпретації все того ж Другого начала термодинаміки й зменшує оптимізм щодо майбутнього нашого світу. А до банального «фізичні» суто температурні наслідки ентропійного процесу, як то кажуть, «на корені» гасять готову вирватись гіпотезу про ентропію як процес переходу ма- 
терії у ту форму буття, що у філософії найзагальніше означається як духовне. Однак з іншої сторони, думки про «відкритість простору» як необхідну умову для існування, функціонування та саморозвитку природних об'єктів і нібито «автономну замкнутість» простору штучних об'єктів [4, с. 31] також не видаються переконливими. Закладені В. Вернадським ідеї отримали на сьогодні потужну підтримку, а деякі представники фізико-математичної галузі науки доволі аргументовано обговорюють гіпотези впливу розумного життя навіть на перебіг надзвичайно масштабних природних космічних процесів. Так, автор ряду наукових досліджень (серед яких «Філософські проблеми астрономії XX століття» та ін.) Ф.А. Цицин аналізуючи проблеми, які виходять 3 Другого начала термодинаміки, зазначає: «Очевидно, що при достатньо високому рівні енергетичної потужності космічна цивілізація стає фактором вже не тільки космогонічного, але й космологічного масштабу, навіть будучи обмеженою II началом. [...] Однак космічна цивілізація, що подолала межі II Начала ... може ініціювати зміну протікання космічної термодинамічної еволюції і характеру термодинамічного стану матерії в своїй окрузі, вихід матерії і енергії із стану „теплової смерті“ в скільки завгодно великому, необмежено розширюваному з часом „Всесвіті Ньютона-Больцмана“”» [14, с. 155]. Отже, можливість тривалої еволюції розуму та розширення меж його впливу на неживу природу видається більш ніж вірогідною. Мені вже доводилось висловлювати думку про те, що ідея еволющії розуму (духу, свідомості) до стану, здатного не тільки впливати на неживу природу, але й навіть започатковувати матерію, не видається більш дивною і неможливою, ніж визнана на сьогодні наукова ідея про еволюцію матерії до стану, коли вона стає здатною започаткувати життя та забезпечити його розвиток до стадії розуму і духу [7]. Що ж до «фізичності» показників ентропії, то варто згадати, що число, посередництвом якого цей процес не тільки вимірюється й описується людиною, але через яке й реально реалізується буття (через природні, космічні ритми й вібрації) здавна розглядалося філософією як «естетичний і онтологічний першопринцип» [5, с.506]. Однак ця тема потребує окремого обговорення, яке виходить за межі даної публікації.

Загалом щодо функціонування понять природного й штучного у сучасній людській культурі можна зауважити таке:

- Сприйняття людиною будь-якого об'єкту чи процесу як природного чи штучного у багатьох аспектах є суб'єктивним і залежить не стільки від самого об'єкту, скільки від змісту й спрямованості 
людської свідомості.

- Поява нових об'єктів, процесів, станів є закономірністю буття, і створення людиною «штучних» об'єктів чи станів (у тому числі й станів природного середовища) є тільки ланкою цього загального руху матерії. Не знаходиться, на мій погляд, аргументів, які б свідчили про зупинення руху й еволюції саме на даному їх етапі.

- Оскільки опредметнення понять природного й штучного історично змінюється й оновлюється, то у філософському дискурсі слід виходити не з жорсткого й статичного опозиційного їх протиставлення, а з розуміння штучного як свого роду природного новоутворення. Слід враховувати, що факт поступового оновлення предметного змісту понять природного й штучного утворює спрямовану динамічну нестабільність їх змістовності.

\section{1 Бібліографія}

[1] Дзикевич C.A. Эстетика онтологии. Эпистемологическая аналитика знания бытия. - М., 2006.

[2] Иванов В.В. Место человека в космосе. Антропный принцип. Лекция, прочитанная в РГГУ 1 сентября 2003 года. // http://kogni.narod.ru/lectio1.htm

[3] Кант И. Критика способности суждения // Иммануил Кант. Сочинения в шести томах. - Т. 5.-М.: Мысль, 1966.

[4] Карамишева $H$. Природне й штучне як властивості креативних об'єктів // Вісник Львівського університету. Філософські науки. 2004. 一№6. - C. 27-34.

[5] Лосев А.Ф. История античной эстетики (ранняя классика). - М.: Государственное издательство «Высшая школа», 1963.

[6] Матвєєва Л.Л. Технології клонування в контексті проблематики творчої активності людини // Практична філософія. - 2007. № $1 .-$ C. $63-68$.

[7] Матвєева Л.Л. Антропне буття в контексті питань про сутність та еволюцію Всесвіту // Практична філософія. - 2005. - № 3. C. $67-76$. 
[8] Матвеєва Л.Л. Роль художнього відтворення минулого в існуванні культурно-етичного песимізму // Актуальні проблеми духовності. Збірка наукових праць. Випуск 7. - Кривий Ріг, 2006. C. 33-43.

[9] Плеснер X. Ступени органического и человек: Введение в философскую антропологию / Пер. с нем. - М.: Российская политическая энциклопедия (РОССПЭН), 2004.

[10] Рингер $\Phi$. Закат немецких мандаринов (избранные главы) // http://simulacres.by.ru/texts/ztk/ringer_mandariny.htm.

[11] Саймон Г. Науки об искусственном. - М., 1972.

[12] Татаркевич В. Історія шести понять.-К.: Юніверс, 2001.

[13] Хайдеггер M. Положение об основании // М. Хайдеггер. Положение об основании. Статьи и фрагменты. - СПб.: Лаборатория метафизических исследований философского факультета СПбГУ; Алетейя, 2000.

[14] Цицин Ф.А. Термодинамика, Вселенная и флуктуации // Вселенная, астрономия, философия. - М.: Изд-во МГУ, 1988. 